\title{
Biological considerations in the measurement of dissolved free amino acids in seawater and implications for chemical and microbiological studies*
}

\author{
Jed A. Fuhrman \& Trudy M. Bell \\ Marine Sciences Research Center, State University of New York, Stony Brook, New York 11794, USA
}

\begin{abstract}
Dissolved free amino acids (DFAAs) are a significant source of carbon and nitrogen for marine bacteria. The various organisms present in coastal surface seawater contain amounts of free amino acids far greater than those dissolved in the water they occupy, and certain common ways of treating seawater samples can lead to release from cells, yielding abnormally high amounts of DFAAs. In this study, filtration of 5,10 and $25 \mathrm{ml}$ volumes through 0.2 to $0.45 \mu \mathrm{m}$ pore size membrane filters yielded similar DFAA concentrations as measured by high pressure liquid chromatography, but filtrations of $50 \mathrm{ml}$ or more apparently led to DFAA release. Filter pore size and type had an effect; 0.2 $\mu \mathrm{m}$ polycarbonate Nuclepore ${ }^{\circledR}$ and 0.22 or $0.45 \mu \mathrm{m}$ mixed cellulose ester Millipore ${ }^{\circledR}$ filters gave similar results, but $1.0 \mu \mathrm{m}$ Nuclepore ${ }^{\infty 8}$ or Whatman GF/F glass fiber filters apparently induced DFAA release from organisms, even with volumes as small as $10 \mathrm{ml}$. These results indicate that some previous studies of DFAA concentrations or microbiological rate measurements may have been significantly affected by filtration artifacts. Such artifacts may also involve other dissolved components.
\end{abstract}

\section{INTRODUCTION}

From both chemical and biological points of view and for a variety of reasons, there has been recent interest in measuring the concentrations of dissolved free amino acids (DFAAs) in seawater. DFAAs are a subclass of dissolved organic matter (DOM), which can take part in a variety of abiotic reactions (Bada \& Lee 1977, Pocklington 1977, Hedges 1978), and are also readily taken up, largely by bacteria and to a small extent by phytoplankton (Fuhrman \& Azam 1982). Uptake of DFAAs represents a very important source of carbon and nitrogen for heterotrophic bacteria (Crawford et al. 1974, Williams \& Yentsch 1976, Hollibaugh et al. 1980, Jørgensen 1982). Given the recent observation that up to half of the total primary production in coastal pelagic systems passes through the bacteria (Hagström et al. 1979, Fuhrman \& Azam 1980, 1982, Williams 1981), information on sources of bacterial nutrition is of particular significance.

\footnotetext{
- Contribution No. 471 of the Marine Sciences Research Center
}

Recent analytical advances allow measurement of DFAAs in seawater, by high pressure liquid chromatography (HPLC) of derivatized products, without the need for concentration or extraction steps which may alter concentrations (Lindroth \& Mopper 1979, Mopper \& Lindroth 1982). This fact, combined with the intrinsic importance of DFAAs to bacteria, makes DFAAs a particularly good model for studies of biologically useful DOM in seawater.

However, care must still be taken to avoid changing the DFAA levels before analysis. It is important to consider that significant intracellular pools within microorganisms may be released in whole or part upon physical or chemical treatment. Intracellular concentrations of DFAAs within laboratory-cultured algae are typically near 100 to 200 millimolar (Wheeler 1983). A simple calculation shows that release of even $1 \mathrm{mM}$ individual intracellular amino acid pools from, say, $10^{6}$ algal cells $1^{-1}$ each with an average diameter of $30 \mu \mathrm{m}$ (rough numbers from coastal waters; Parsons et al. 1977 ) would yield about $14 \mathrm{nM}$ 'contamination' by each intracellular amino acid. This represents a significant potential contribution compared to the tens to 
hundreds nanomolar total DFAAs reported for coastal waters (Mopper \& Lindroth 1982).

Filtration of water samples before DFAA measurement has 3 advantages. First, with unfiltered samples, chemical treatment for derivatization or harsh physical treatment (high-pressure flow through narrow-bore tubing and stainless steel frits) may easily damage delicate microplankton cells and induce DFAA release. Second, filtration stops the natural uptake and release processes that may be altered by sample collection and handling. Because these processes can be rapid, with turnover times of hours or less (Jørgensen 1982, Fuhrman 1983), concentrations could quickly change in unfiltered samples. Third, filtration removes the siliceous or calcareous hard parts common among microplankton which could damage injection seals or clog the frits of the HPLC. The process of filtration, however, can introduce its own artifacts. Assessing such artifacts, and choosing techniques that minimize them, was a primary goal of this study.

We aimed to develop procedures to minimize biologically mediated artifacts in DFAA measurement. We observed that addition of a toxic substance (in this case $\mathrm{HgCl}_{2}$ ) to seawater caused a drastic increase in DFAAs, presumably from injured or dead plankton. In an evaluation of filtration techniques we found that with samples from coastal waters, gentle vacuum filtration of small (5 to $25 \mathrm{ml}$ ) volumes through Millipore ${ }^{(8)}$ or $0.2 \mu \mathrm{m}$ Nuclepore ${ }^{\circledR}$ filters had minimal effects, but larger volumes $(50$ to $350 \mathrm{ml})$ and larger pore size $(1.0$ $\mu \mathrm{m})$ Nuclepore ${ }^{B}$ filters appeared to cause DFAA release from plankton. These observations have significant consequences regarding the interpretation of previously published studies and the planning of new ones.

\section{MATERLALS AND METHODS}

HPLC apparatus and operating conditions. The HPLC consisted of a Spectra Physics (Mountain View, California) model 8700 solvent delivery system with static mixer, a Rheodyne 7125 injection valve with $500 \mu l$ loop, a Kratos (Ramsey, New Jersey) model FS 970 fluorometer, and a Spectra Physics model 4270 integrator. The columns used were a $3.2 \times 100 \mathrm{~mm}$ stainless steel column packed in acetone-methanol at $400 \mathrm{~atm}$ pressure with $3 \mu \mathrm{m}$ spherical Rosil C18 silica from Alltech Associates (until 18 Jan 1984) and since then a commercially packed $4.6 \times 100 \mathrm{~mm}$ Microsorb C18 silica column from Rainin (Woburn, Massachusetts).

The amino acid derivatization procedure was modified from Mopper \& Lindroth (1982). The derivatizing solution consisted of $25 \mathrm{mg}$ o-phthaldialdehyde (Pierce; Rockford, Illinois), $25 \mu$ l 2-mercaptoethanol
(Pierce), and $500 \mu l$ methanol (Burdick and Jackson; Muskegon, Michigan), mixed with $500 \mu \mathrm{l}$ of $1 \mathrm{M}$ sodium borate buffer, pH 13 (adjusted from Pierce $\mathrm{pH} 10.4$ buffer with $10 \mathrm{M} \mathrm{KOH}$ ). Ten $\mu \mathrm{I}$ of this solution were added to a $1 \mathrm{ml}$ sample and mixed vigorously. After exactly $1 \mathrm{~min}, 5 \mu \mathrm{l}$ of $10 \%$ glacial acetic acid was added to stop the reaction. This step was found to reduce the blank, probably by preventing derivatization of contaminants in the mobile phase. The syringe was rinsed with approximately $200 \mu$ l of the sample, and then $250 \mu \mathrm{l}$ was injected into the HPLC. Blanks were prepared with filtered $10.22 \mu \mathrm{m}$ pore size Millipore $\left.{ }^{(\mathbb{B}}\right)$ HPLC grade water (Burdick and Jackson) instead of a seawater sample. A 50nM alpha aminobutyric acid internal standard was added to samples just before derivatization in experiments after 5 July 1984.

Mobile phases (all HPLC grade) were: (A) $50 \mathrm{mM}$ sodium acetate adjusted to $\mathrm{pH} 5.8$ with acetic acid, $2 \%$ tetrahydrofuran by volume, and (B) methanol (Jones et al. 1981). The exact gradients used were not constant over the course of this study, but were generally close to 25 to $80 \%$ B in $18 \mathrm{~min}$, returning to initial conditions at $20 \mathrm{~min}$, at a constant flow rate of $1 \mathrm{ml} \mathrm{min} \mathrm{m}^{-1}$. Early experiments with the non-commercial columns did not allow quantification of the amino acids eluting after tyrosine. Experiments after February 1984 employed a complex gradient in order to improve the resolution of some amino acid pairs. This gradient, and typical blank, standard, and seawater runs are shown in Fig. 1. In most cases, glycine and threonine were not completely resolved, and ammonium concentrations greater than about $0.5 \mu \mathrm{M}$ interfered with valine.

Peaks were identified by their characteristic retention times; sometimes it was necessary to spike samples with individual DFAA standards to confirm identification of peaks that eluted close to others (e.g. arginine and taurine). Quantification was by peak area linearly compared to standards (Pierce or Sigma), although sometimes peak heights were used when the peaks were integrated improperly. Most results are averages of independently filtered duplicates. Occasional very high concentrations in 1 replicate were assumed to be contaminants and were ignored; in some of these cases, a third sample was filtered and analyzed. The average range of duplicate determinations of individual amino acids was the mean $\pm 18 \%$ (from 195 sets of duplicates).

Sampling location and procedure. All water samples were collected from a pebble beach at Crane Neck, New York, on Long Island Sound $\left(40^{\circ} 55.3^{\prime} \mathrm{N}, 73^{\circ}\right.$ $09.3^{\prime} \mathrm{W}$ ). Sample bottles (1 to $3 \mathrm{l}$ ) were of polymethylpentene, polycarbonate, or polypropylene and had been soaked in $0.6 \mathrm{~N} \mathrm{HCl}$ overnight and copiously rinsed with deionized water and sample water before 
Fig. 1. (A) Mobile phase gradient for DFAA separations (mobile phases described in text). (B) Blank chromatogram with derivatized HPLCgrade water. The large peak is an added $50 \mathrm{nM}$ alpha-amino butyric acid internal standard. (C) Standard run with $50 \mathrm{nM}$ of each added amino acid. Peaks are: 1, aspartic acid; 2, glutamic acid; 3, serine; 4, histidine; 5 , glycine; 6 , threonine; 7 arginine; 8 , alanine; 9 , tyrosine; 10, alpha-amino butyric acid; 11 , methionine; 12 , valine; 13 , phenylalanine; 14 , isoleucine; 15, leucine. (D) Natural water sample from Chesapeake Bay (1 Oct 1984). Identification numbers as in (C); others are: a, unknown (occurs in non-derivatized samples, so is not an amino acid); b and $\mathrm{f}$, unknown; $\mathrm{c}$, asparagine; $\mathrm{d}$, glutamine; e, taurine; g, ammonium
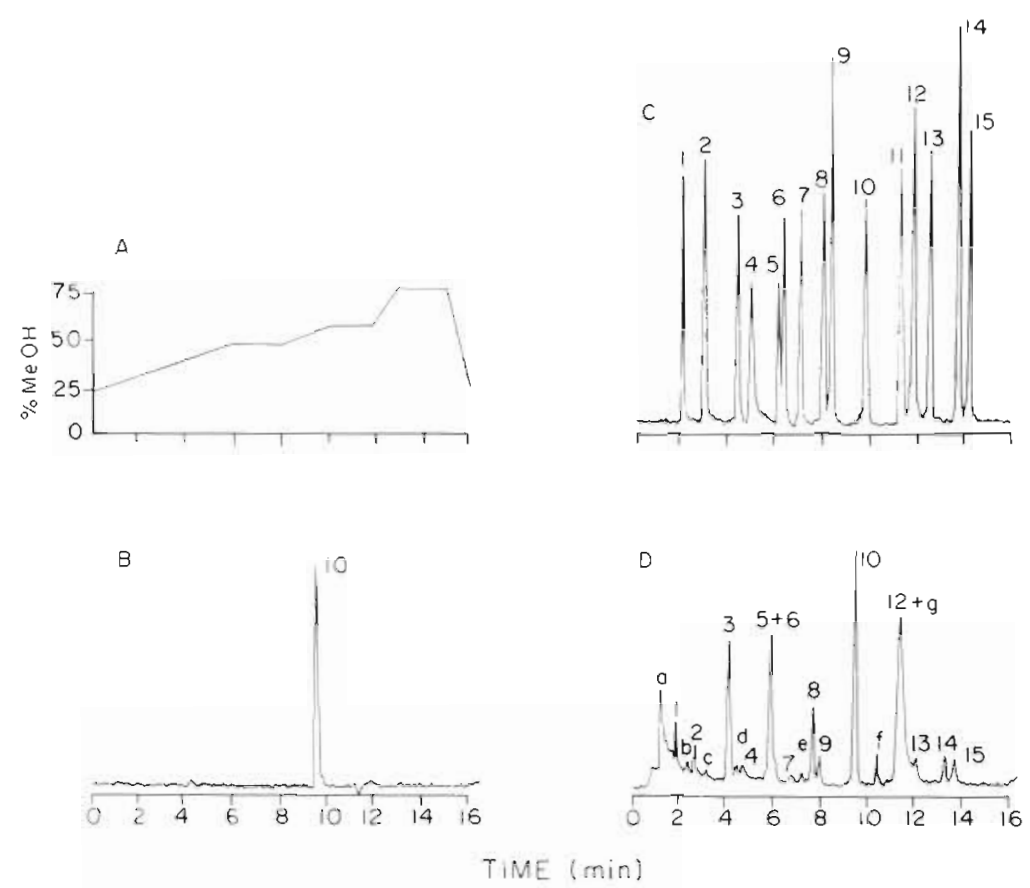

filling. Samples were returned to the lab within $20 \mathrm{~min}$ of collection. In the lab, samples were kept in a lighted incubator (ca $10 \%$ surface sunlight) within 1 to $2 \mathrm{C}^{\circ}$ of the original water temperature. Subsamples for various treatments were stored within the incubator in prerinsed sterile polyethylene Whirlpak ${ }^{(i)}$ bags.

Filtration. The filter types used were $25 \mathrm{~mm}$ diam. $0.45 \mu \mathrm{m}$ pore size cellulose mixed ester (Millipore ${ }^{(i)}$ type HA), $47 \mathrm{~mm}$ diam. $0.22 \mu \mathrm{m}$ pore size cellulose mixed ester (Millipore ${ }^{\circledR}$ type GS), and both 25 and 47 $\mathrm{mm}$ diam. $0.2 \mu \mathrm{m}$ and $1.0 \mu \mathrm{m}$ pore size polycarbonate Nuclepore ${ }^{\circledR}$ filters. All filters were rinsed several times with a few $\mathrm{ml}$ of freshly filtered $(47 \mathrm{~mm}$ diam., $0.22 \mu \mathrm{m}$ pore size Millipore $\left.{ }^{\circledR}\right)$ HPLC grade water before use. Samples of $15 \mathrm{ml}$ or less were filtered through $25 \mathrm{~mm}$ diam. filters on an acid-washed (10\% nitric) 10 -place manifold with stainless steel bases and funnels and teflon valves (Hoefer Scientific; San Francisco, California); a rack allowed collection of individual filtrates in acid-washed polypropylene scintillation vials. For larger volumes, $47 \mathrm{~mm}$ filters were used with an acidwashed polycarbonate and polypropylene filter unit (Millipore Corp.). Filtrates from the $47 \mathrm{~mm}$ filters were stored in cleaned scintillation vials. All filtered samples were stored at 0 to $4^{\circ} \mathrm{C}$. Volumes filtered and vacuum pressures varied for specific experiments (see below). All pipette tips and graduated cylinders used for sample measurement were acid washed.

Methanol extraction. On 17 September 1984, duplicate $10 \mathrm{ml}$ water samples were filtered $(<3 \mathrm{~cm} \mathrm{Hg}$ vacuum pressure differential) through $25 \mathrm{~mm}$ diam. $0.2 \mu \mathrm{m}$ pore size Nuclepore ${ }^{\circledR}$ filters. The filtrates were analyzed for DFAAs and the material on the filters was extracted for $1 \mathrm{~h}$ at $4^{\circ} \mathrm{C}$ in HPLC-grade methanol. The methanol was evaporated in vacuo and $10 \mathrm{ml}$ of HPLCgrade water was added and thoroughly mixed. The water was filtered through $0.2 \mu \mathrm{m}$ pore Nuclepore ${ }^{\circledR}$ filters and then analyzed for DFAAs.

Mercuric chloride effect on release and uptake. On 13 May 1983, a seawater sample was divided into two $100 \mathrm{ml}$ subsamples. $\mathrm{HgCl}_{2}$ at $516 \mathrm{nM}$ (final concentration) was added to one subsample and the other was untreated. Five min after addition of $\mathrm{HgCl}_{2}, 0.1 \mathrm{nM}$ of tritiated glutamic acid (ICN) was added to each sample. Within $1 \mathrm{~min}$, and at $1 \mathrm{~h}$ and $2.5 \mathrm{~h}, 10 \mathrm{ml}$ subsamples from each were filtered through $25 \mathrm{~mm}$ diam. HA Millipore ${ }^{\circledR}$ filters. The filtrate was used for DFAA analysis and also for measurement of radioactivity (by liquid scintillation) before and after lyophilization. The difference between the radioactivity in the filtrate and in the lyophilized filtrate was considered to be due to tritiated water produced by respiration of the label. The filters were rinsed 5 times with filtered seawater and assayed for radioactivity to measure the label incorporated into microorganisms. Total uptake of label was calculated in 2 ways which gave similar results: (1) by appearance of label on the filter plus that in tritiated water; (2) by disappearance of label with time in the lyophilized filtrates. Counting efficiencies were determined with both external and internal standards.

Effect of volume filtered. On 6 and 19 July 1984, increasing volumes (10 to $200 \mathrm{ml}$ ) of seawater were filtered through the same $47 \mathrm{~mm}$ GS Millipore ${ }^{\circledR}$ filter at $3 \mathrm{~cm} \mathrm{Hg}$ vacuum pressure differential. Between additions, the previous filtrate was completely removed for 
DFAA analysis. At the same time, $10 \mathrm{ml}$ samples were filtered through $25 \mathrm{~mm}$ HA Millipore ${ }^{\circledR}$ filters at $3 \mathrm{~cm}$ $\mathrm{Hg}$ vacuum. On 14 September 1984, duplicate $5 \mathrm{ml}$ and $10 \mathrm{ml}$ samples were filtered through $25 \mathrm{~mm}$ HA Millipore ${ }^{\circledR}$ filters and duplicate $25 \mathrm{ml}$ samples were filtered through $47 \mathrm{~mm}$ GS Millipore ${ }^{\circledR}$ filters, all at $3 \mathrm{~cm} \mathrm{Hg}$ vacuum. On 28 March 1985, quadruplicate $15 \mathrm{ml}$ and triplicate $100 \mathrm{ml}$ samples were filtered through $47 \mathrm{~mm}$ GS Millipore ${ }^{(1)}$ filters.

Effect of vacuum pressure differential. On 3 and 17 July 1984, $10 \mathrm{ml}$ seawater samples were filtered through $25 \mathrm{~mm}$ filters at various pressure differentials between 3 and $64 \mathrm{~cm} \mathrm{Hg}$. Triplicate filtrations were performed at each pressure.

Effect of $1 \mathrm{\mu m}$ filtration. On 8 November 1983, DFAAs were measured from both a previously unfiltered sample and a $500 \mathrm{ml}$ sample which had been filtered ( $<15 \mathrm{~cm} \mathrm{Hg}$ vacuum) through a $47 \mathrm{~mm}$ diam. $1.0 \mu \mathrm{m}$ Nuclepore ${ }^{(1)}$ filter. $10 \mathrm{ml}$ subsamples from each were filtered through $25 \mathrm{~mm}$ HA Millipore ${ }^{\circledR}$ filters ( 3 $\mathrm{cm} \mathrm{Hg} \mathrm{vacuum)} \mathrm{before} \mathrm{analysis.} \mathrm{A} \mathrm{second} \mathrm{experiment}$ on 7 December was similar to the above except $100 \mathrm{ml}$ had been filtered through the Nuclepore ${ }^{\circledR}$ filter.

To be sure that differences in DFAA concentrations were not due to contamination introduced by the apparatus used for $1 \mu \mathrm{m}$ filtration, a third experiment on 20 December used samples treated in 3 ways: (1) filtration through Millipore filters only; (2) filtration through Millipore ${ }^{\circledR}$ filters first and then immediately through $1.0 \mu \mathrm{m}$ Nuclepore ${ }^{\circledR}$ filters; (3) filtration through $1.0 \mu \mathrm{m}$ Nuclepore ${ }^{\circledR}$ filters first and then immediately through Millipore ${ }^{\circledR}$ filters. This 3-way treatment was done with both $10 \mathrm{ml}$ volumes $(25 \mathrm{~mm}$ diam. filters) and with $100 \mathrm{ml}$ volumes $(47 \mathrm{~mm}$ diam. filters). This experiment was repeated, without the Millipore ${ }^{\circledR}$ filtration only, on 28 and 29 March 1985 wiht triplicate $15 \mathrm{ml}$ volumes (25 $\mathrm{mm}$ diam. filters).

Effect of glass fiber filtration. On 16 November 1984 , an experiment similar to the third $1 \mu \mathrm{m}$ filtration experiment was performed with $25 \mathrm{~mm}$ diam. Whatman GF/ $F$ glass fiber filters $(0.7 \mu \mathrm{m}$ rated pore size) instead of 1 $\mu \mathrm{m}$ Nuclepore ${ }^{\circledR}$ filters $(10 \mathrm{ml}$ volumes only). The filters had been precombusted at $400^{\circ} \mathrm{C}$ for 3 h to eliminate organic contaminants.

\section{RESULTS}

\section{Methanol extraction}

The extract had the same volume as the water filtered, so a direct comparison on a per-unit-volume basis can be made. About $84 \%$ of the total dissolved + extractable amino acids in the sample was in the extractable pool (Fig. 2). The most abundant extract-

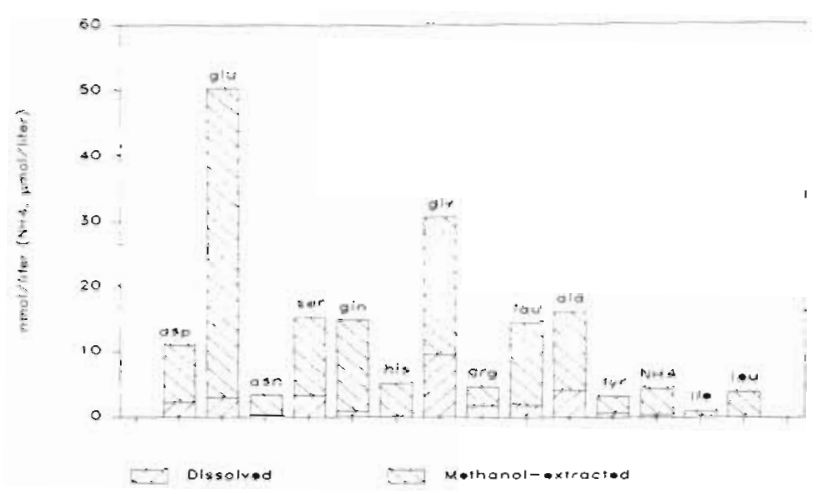

Fig. 2. Dissolved and methanol-extracted DFAAs from 17 September, 1984, plotted on an equivalent water volume basis. Data are averages of duplicate determinations. Amino acids not shown were not quantified

abie amino acids were glutamic acid, glycinef threonine, glutamine, and serine.

\section{$\mathrm{HgCl}_{2}$ effect}

Within $5 \mathrm{~min}$ of the addition, there was no obvious effect of the $\mathrm{HgCl}_{2}$ on the DFAA concentrations, but by $1 \mathrm{~h}$, the total of the measured DFAAs had quadrupled, while those in the untreated sample had slightly declined (Fig. 3). A further, but not so dramatic,

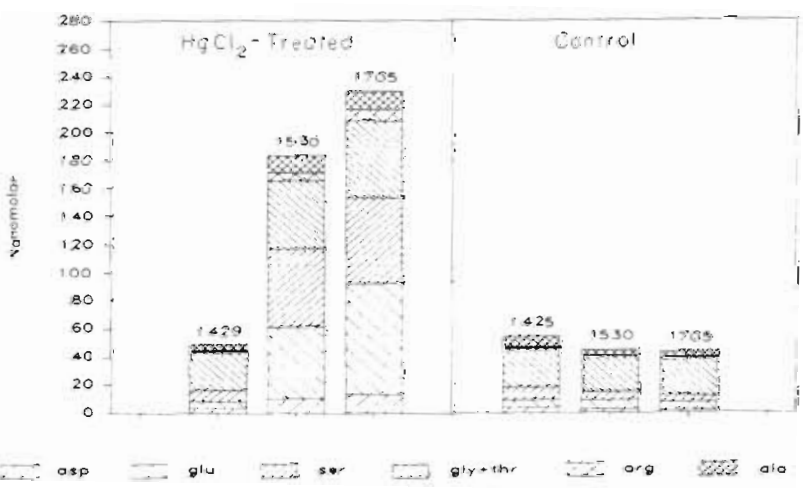

Fig. 3. Effect of $\mathrm{HgCl}_{2}$ addition on DFAA concentrations. $\mathrm{HgCl}_{2}$ was added to 1 sample at $1424 \mathrm{~h}$. Time of filtration is shown above each bar

increase was seen the treated sample by $2.5 \mathrm{~h}$, while the untreated sample stayed about the same. Of the amino acids measured, the biggest increases in the treated sample occured in serine and glutamic acid, but all DFAAs were affected.

The $\mathrm{HgCl}_{2}$ affected the uptake of tritiated glutamic acid within minutes. The treated sample showed virtually no uptake, while in the untreated sample, the tritiated glutamic acid had a turnover time of $0.6 \mathrm{~h}$ (measured as the concentration in $\mathrm{nM}$ divided by the uptake rate in $n \mathrm{M} \mathrm{h}^{-1}$ ). 


\section{Effect of volume filtered}

In each of the experiments with larger volumes, increasing the volume filtered from 10 to $50 \mathrm{ml}$ or greater increased the DFAA concentrations in the filtrates to a significant extent $(\mathrm{P}<0.05$ in each experiment, rank sum test comparing pooled $10 \mathrm{ml}$ and $>40$ ml filtrations within experiments; Fig. 4). Individual
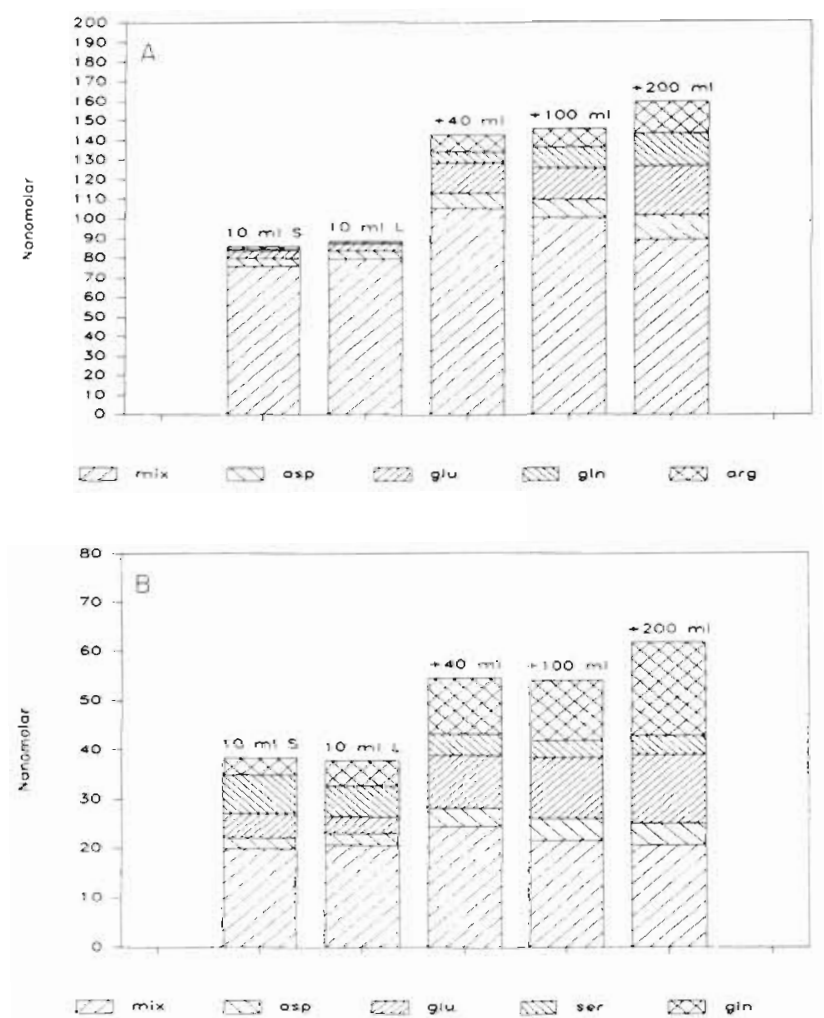

Fig. 4. Volume effect on DFAA concentrations in filtrates. (A) 6 July 1984; (B) 19 July 1984. Numbers above each bar are volumes of water filtered; + indicates that the same filter was used as for the bar on its left, although the previous filtrate had been removed. S: $25 \mathrm{~mm}$ diameter filter; $\mathrm{L}: 47 \mathrm{~mm}$ filter. Lowest bar in each stack represents the total of gly/thr, ala, tyr, ile, leu, ser (A only) and arg (B only). All numbers are averages of duplicates (not shown, but used for statistical tests)

DFAA data for the 28 March 1985 experiment are not shown, but the total DFAAs in the quadruplicate $15 \mathrm{ml}$ filtrates was $42 \pm 3.2 \mathrm{nM}$ (mean \pm standard error), and in the triplicate $100 \mathrm{ml}$ filtrates, $81 \pm 12.1 \mathrm{nM}$. There were particularly large increases in glutamic acid and glutamine, and also sometimes in arginine. The experiment comparing just smaller volumes showed no significant differences between the DFAA concentrations when 5,10 , or $25 \mathrm{ml}$ were filtered (Table 1). The diameter of the filter ( $25 \mathrm{~mm}$ or $47 \mathrm{~mm}$ ) had no significant effect on the filtrate DFAA concentration when 10 or $25 \mathrm{ml}$ samples were filtered (Fig. 4; Table 1).
Table 1. DFAAs in filtrates, after filtration of different small volumes

\begin{tabular}{|cc|}
\hline Volume filtered $(\mathrm{ml})$ & Total DFAA conc. (nM) \\
\hline 5 & $118.2-124.0$ \\
10 & $121.4-123.0$ \\
25 & $109.1-118.1$ \\
& \\
- Values are the range of duplicate filtrations. The DFAAs \\
quantified were the same as in Fig. 2
\end{tabular}

\section{Effect of vacuum pressure differential}

With $10 \mathrm{ml}$ samples, variation of vacuum differentials from 3 to $64 \mathrm{~cm} \mathrm{Hg}$ had a minor effect on the DFAA concentrations, with 1 experiment showing a $20 \%$ increase between lowest and highest vacuums, and the other demonstrating a $10 \%$ decrease; no statistically significant pattern was seen (Fig. 5). There was

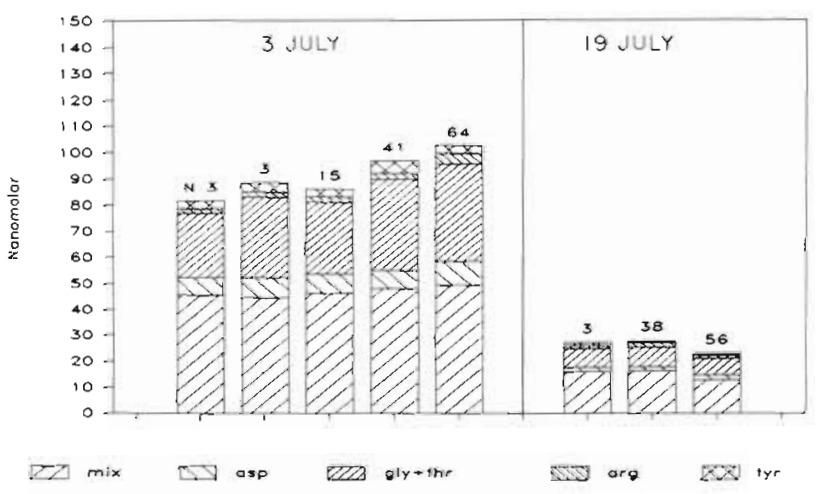

Fig. 5. Effect of vacuum pressure differential on DFAA concentrations. Numbers above each bar are differentials in $\mathrm{cm}$ Hg. Leftmost bar is from a $0.2 \mu \mathrm{m}$ pore-size Nuclepore ${ }^{\circledR i l t e r}$; all others are from $0.45 \mu \mathrm{m}$ pore Millipore ${ }^{\circledR}$ filters. Bottom bar in each stack represents total of glu, ser, ala, ile, and leu. All numbers are averages of duplicates

also no significant difference in DFAAs when $0.2 \mu \mathrm{m}$ Nuclepore ${ }^{\circledR}$ filters were compared to $0.45 \mu \mathrm{m}$ Millipore ${ }^{\circledR}$ filters at low vacuum differentials (Fig. 5, left).

\section{Effect of $1 \mu \mathrm{m}$ Filtration}

Filtering $500 \mathrm{ml}$ through a $1 \mu \mathrm{m}$ Nuclepore ${ }^{\circledR}$ filter increased the measured DFAA concentration from 63 to $126 \mathrm{nM}$ (Fig. 6A). On a separate date, $1 \mu \mathrm{m}$ filtration of $100 \mathrm{ml}$ of seawater increased the total concentration a lesser and possibly insignificant amount, from about 33 to $44 \mathrm{nM}$, but glutamate increased 5-fold (Fig. 6A). The third experiment was performed to see if any of the 

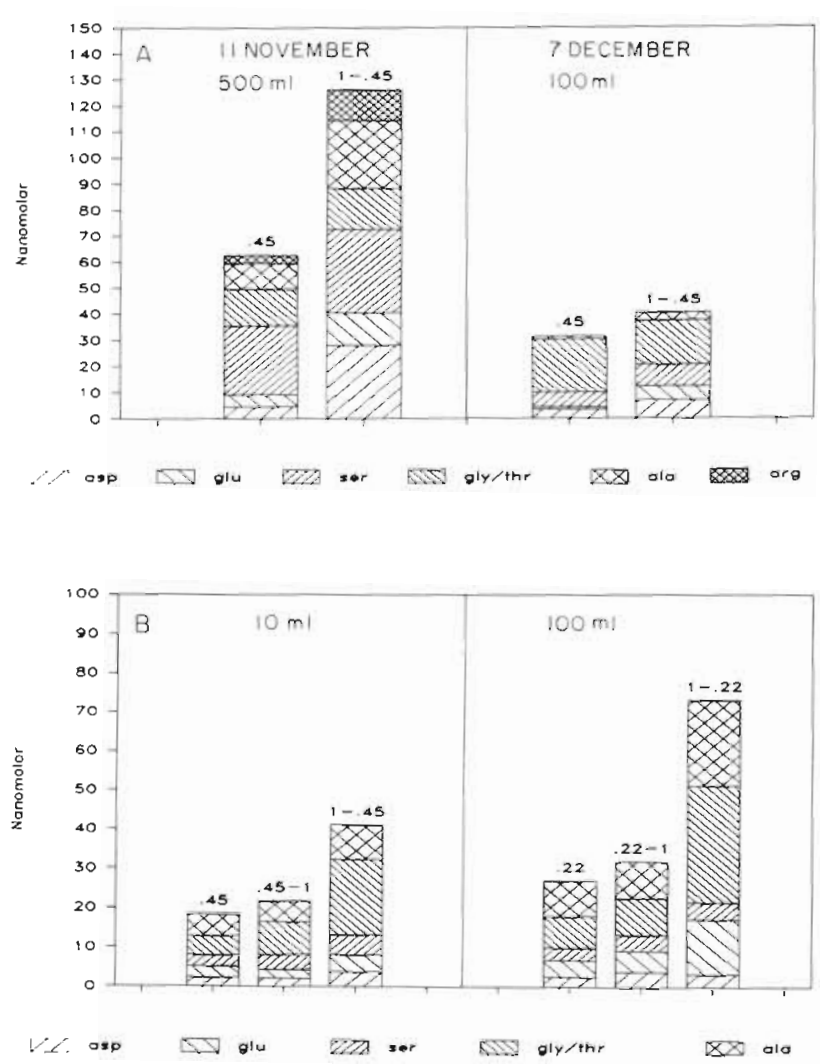

Fig. 6. Effect of $1 \mu \mathrm{m}$ pore size Nuclepore ${ }^{B}$ filtration on DFAA concentrations. (A) Left member of each pair was Millipore ${ }^{B}$ filtered only. Either $500 \mathrm{ml}$ (left pair) or $100 \mathrm{ml}$ (right pair) were filtered through a $1 \mu \mathrm{m}$ Nuclepore ${ }^{\circledR}$ filter, and $10 \mathrm{mI}$ were subsequently Millipore ${ }^{\circledR}$-filtered $(0.45 \mu \mathrm{m})$ for DFAA measurement (right member of each pair). (B) In each group of 3, left is Millipore ${ }^{\$}(0.45$ or $0.22 \mu \mathrm{m})$ filtered only, middle is Millipore ${ }^{(1)}$ and then $1 \mu \mathrm{m}$ Nuclepore ${ }^{\sqrt{(1)}}$ filtered, and right is 1 $\mu \mathrm{m}$ Nuclepore ${ }^{\otimes}$ and then Millipore ${ }^{\circledR}$ filtered. Left three are with $10 \mathrm{ml}$ samples and $25 \mathrm{~mm}$ diameter filters; right three are with $100 \mathrm{ml}$ samples and $47 \mathrm{~mm}$ diameter filters

increases were due to contamination from the filters or filter units; comparisons were made between water that had been through the same filter units - only the order of filtration was changed. The data show that both with $10 \mathrm{ml}$ samples filtered through $25 \mathrm{~mm}$ filters and with $100 \mathrm{ml}$ samples filtered through $47 \mathrm{~mm}$ filters, the DFAAs approximately doubled in concentration when the water was first filtered through the $1 \mu \mathrm{m}$ Nuclepore ${ }^{\circledR}$ filters (Fig. 6B). All of the measured amino acids showed the increases. There were insignificant increases when the Millipore ${ }^{\circledR}$-filtered water was subsequently filtered through the $1 \mu \mathrm{m}$ Nuclepore ${ }^{\circledR}$ filters (Fig. 6B). Repeating this experiment on 28 and 29 March 1985 with triplicate samples showed that the increases upon $1 \mu \mathrm{m}$ filtration were statistically significant (both days $P=0.05$, rank sum test). The total DFAA concentrations increased from $42 \pm 3.2 \mathrm{nM}$ (mean \pm standard error) to $164 \pm 17.9$ nM on 28
March, and from $30 \pm 5.8 \mathrm{nM}$ to $57 \pm 6.8 \mathrm{nM}$ on 29 March.

Note that the third experiment also demonstrated the volume effect; the $100 \mathrm{ml}$ Millipore ${ }^{(\mathrm{B})}$-filtered samples had about $50 \%$ higher DFAAs than the $10 \mathrm{ml}$ samples (Fig. 6B). All the measured amino acids increased to some extent, with the largest percentage increases in glutamic acid, glycine + threonine, and alanine.

\section{Effect of glass fiber filtration}

The sample first filtered through the glass fiber filter had significantly higher DFAAs (mean total $44 \mathrm{nM}$ ) than that first filtered through the Millipore ${ }^{\circledR}$ filter (mean total $13 \mathrm{nM}$ ). All the measurable DFAAs increased. The dominant DFAAs were glycine, serine, and alanine.

\section{DISCUSSION}

In the introduction, a rough calculation (from literature data on cultures and abundance) suggested that release of a portion of the free amino acid pools from 'typical' coastal phytoplankton could add >10 nM of each of several amino acids to seawater. In this study, when methanol was used to extract soluble amino acid pools from particulate material (presumably mostly microorganisms), the extractable DFAAs totaled about $150 \mathrm{nM}$ when diluted into the original water volume, compared to about $28 \mathrm{nM}$ of 'truly' dissolved DFAAs (Fig. 2). This confirms the significant potential for error in the measurement of DFAAs unless care is taken to avoid damage and release from organisms. As expected, some of the amino acids in the extract were far more abundant than others. Glutamic acid and glutamine are particularly high, probably because these amino acids play essential roles in the ammonium uptake mechanisms of phytoplankton (Syrett 1981). The source of the relatively large amount of taurine (2-aminoethanesulfonic acid; not a component of protein) is probably microzooplankton; this compound is reported to be abundant among the plankton only in animals (Jeffries 1969).

The concentrations of DFAAs found in natural seawater result from a balance between the processes that release them into the water (primarily from organisms) and those that remove them (e.g. uptake by microorganisms). Treatment of a seawater sample can upset this balance by preferentially affecting release or removal processes. Several of the described treatments caused increases in DFAAs, suggesting either an increase in DFAA release or a decrease in uptake. In the filtration-effect experiments, the increases were 
immediate, suggesting sudden release; subsequent uptake was prevented by the filtration. However, in the $\mathrm{HgCl}_{2}$ experiment, the effect was not immediately apparent. Also, in that experiment, the labeled glutamate tracer showed that uptake was quickly stopped by the $\mathrm{HgCl}_{2}$. Thus the DFAA increase observed over time in that experiment could be due in part to 'natural' release, not balanced by uptake, in addition to any extra release induced by the $\mathrm{HgCl}_{2}$.

Our experimental design allowed us to estimate separately the glutamic acid release rates in the 2 samples, and hence the $\mathrm{HgCl}_{2}$ effect on release alone, because both the changes in ambient DFAA concentrations and the labeled glutamic acid tracer uptake were measured in that experiment. The release rate calculation corrects the net change in concentration for absolute uptake, which is calculated from concentration and tracer turnover rate data. In effect, this calculation is analogous to the 'isotope dilution' technique used for simultaneous calculation of uptake and release of ammonium and phosphate in natural waters (Glibert et al. 1982, Harrison 1983), and a detailed description will be presented in another report (unpubl.). Application of this isotope dilution model to the data from the untreated sample suggests that the release rate of glutamate in the untreated sample was about $10 \mathrm{nM}$ $\mathrm{h}^{-1}$. The release of glutamate in the $\mathrm{HgCl}_{2}$ treated sample was about $44 \mathrm{nM} \mathrm{h}^{-1}$. Thus, it appears that $>75 \%$ of the increase was due to the treatment effect on release alone.

The substantial DFAA release induced by $516 \mathrm{nM}$ $\mathrm{HgCl}_{2}$ shows that a significant portion of the plankton population is damaged and possibly killed by this treatment, and the time lag suggests that the effect takes at least several minutes. This level of $\mathrm{Hg}$ is about $1000 \times$ the ambient levels in very polluted natural waters (Siebers et al. 1981), but this experiment shows, albeit in an extreme way, how addition of toxic substances can greatly affect the measurement of dissolved organic compounds in seawater. Some recent reports concerned with measurement of primary productivity and heterotrophic activity (Carpenter \& Lively 1980, Fitzwater et al., 1982, Ferguson \& Sunda 1984) show that small inadvertent additions of trace metals from sample handling and reagents may significantly inhibit some phytoplankton and bacteria. It appears that a similar problem could exist for measurement of DFAAs and other dissolved organics that may be released from sensitive plankton organisms.

Increasing the volume of water filtered, from 5 to 25 up to $350 \mathrm{ml}$, was found to increase the DFAA concentration in the filtrate significantly. We feel that the effect is relatively minor for volumes less than $25 \mathrm{ml}$ (with our samples) because 5, 10, and $25 \mathrm{ml}$ filtrations had similar DFAA concentrations in the filtrates (Table
1). The exact reason for the effect with larger volumes is unknown, but it may be that as more water is filtered, organisms accumulating on the filter are exposed to significantly more shear as the water flows by. Glutamate and glutamine showed particularly marked increases, an observation consistent with the results from the extraction experiment, which showed these amino acids to be quite abundant intracellularly.

The extent of this volume effect, namely a $>50 \%$ increase in DFAA concentrations between 10 and 50 $\mathrm{ml}$ filtered and nearly a doubling by $350 \mathrm{ml}$ filtered, was somewhat unexpected. In the past, most workers have usually assumed that the concentrations of dissolved substances are unaffected by filtration. In many cases, the conditions of filtration (volume, filter type, vacuum, pressure, or hydrostatic head) go unreported, and when volumes are reported, they commonly range from $100 \mathrm{ml}$ upwards (e.g. Garrasi et al. 1979, Burney et al. 1981). Thus, some of the reported measurements of specific DOM compounds in seawater may be overestimates caused by filtering too large a volume. For future measurements, either the volume effect should be checked for the particular system studied, or small volumes of $25 \mathrm{ml}$ or less should be filtered through each filter (larger volumes, if needed, can be pooled).

The enhancement of DFAAs in large volume filtrates not only affects measurement of specific DOM compounds, but also has implications regarding some techniques currently in use for measurement of microbial processes such as growth and grazing rates. For example, methods recently employed by Wright \& Coffin (1984) for estimating bacterial production and by Landry et al. (1984) for estimating both production and grazing assume that the relatively large volumes of filtered seawater they use in their dilution experiments contain the 'normal' amount of DOM usable by bacteria. Their results may have been influenced to a significant extent by compounds such as DFAAs released during filtration, making it improper to compare growth of diluted and undiluted samples. (It is assumed here that inadvertent introduction of DFAAs from outside the samples, which we find can be a persistent problem even under 'clean' conditions, was avoided in those experiments). For future studies, the same precautions should be taken as are recommended above for chemical measurements.

A further implication of the volume effect is that it may influence measurement of carbon fixation and organic matter release from phytoplankton, typically studied as appearance of dissolved labeled organic compounds in filtrates from C-14 productivity experiments (for critical analyses, see Sharp 1977, Goldman $\&$ Dennet 1985). Because volumes larger than $25 \mathrm{ml}$ are usually filtered for the productivity work, especially in oligotrophic waters, some of the released labeled car- 
bon could be a filtration artifact, no matter how gently the water is filtered. Therefore this measurement should be done with small filtered volumes whenever possible.

The experiments measuring the effect of various vacuum pressure differentials gave the somewhat surprising result that even a moderately high vacuum (64 $\mathrm{cm} \mathrm{Hg}$ ) had only a minor effect on the DFAA concentrations in the filtrates. Apparently, difference in shear between the lowest and highest vacuum pressures was too small to induce DFAA release from the plankton in the samples studied. This does not mean that any water sample can be filtered under high vacuum with impunity ${ }_{i}$ it is possible that other plankton could be more severely affected (Goldman \& Dennett 1985). Also, other types of filtration, such as pressure filtration with a syringe, are capable of generating a pressure differential of several atmospheres, and could easily damage planktonic organisms. The major reason why one would choose to use a high vacuum or pressure filtration would be to speed up filtration of a large volume. Given that even gentle filtration of large volumes seems to itself induce DFAA release, there does not seem to be any reason to resort to anything more than a gentle vacuum.

The results show that gentle vacuum filtration of even $10 \mathrm{ml}$ samples through $1.0 \mu \mathrm{m}$ pore size Nuclepore ${ }^{\circledR}$ or GF/F glass fiber filters can more than double the DFAA concentrations in the filtrates. The data suggest a mechanical effect involving leakage from organisms because water which had been first filtered through a Millipore ${ }^{\circledR}$ filter and then a $1.0 \mu \mathrm{m}$ Nuclepore ${ }^{\circledR}$ or GF/F filter exhibited no significant increases (Fig. 6B). Also, it was already shown that filtration through a $0.2 \mu \mathrm{m}$ pore size Nuclepore ${ }^{\circledR}$ filter was equivalent to that through a Millipore ${ }^{\circledR}$ filter (Fig. 5), so the effect is related to the pore size and not just the filter type. The mechanism by which this presumed cell leakage occurs may be similar to that suggested for the volume effect; organisms on the filter can be damaged by the shear occurring as water passes by. The reason for the effect in volumes as small as $10 \mathrm{ml}$ may be that the relatively rapid filtration through the $1 \mu \mathrm{m}$ Nuciepore ${ }^{\circledR}$ or glass fiber filter leads to high linear water velocities and thus high shear. The glass fiber filter may also puncture delicate cells on the fibers.

The observed effect of $1 \mu \mathrm{m}$ Nuclepore ${ }^{\circledR}$ filtration on DFAA concentrations may help the interpretation and planning of size fractionation studies of amino acid uptake. Some workers have fractionated water samples before adding labeled substrate (e.g. Wheeler et al. 1977), and others have done so afterwards (e.g. Williams 1970, Azam \& Hodson 1977). The DFAA increase upon $1 \mu \mathrm{m}$ filtration observed here suggests filtration after incubation is preferred; with prefiltra- tion, the unlabeled DFAAs released would dilute out the added labeled DFAAs, and the resulting reduced specific activity in the prefiltered sample would make it appear as if a much smaller amount of uptake were occurrring than was actually the case. Perhaps this partly explains why Wheeler et al. (1977) reported a larger percentage of amino acid uptake in the larger size fractions than did Williams (1970). The conclusion of Wheeler et al. (1977) that a large fraction of total amino acid uptake in natural populations can be ascribed to phytoplankton should be re-examined in this light, particularly considering the observation that only a tiny fraction of DFAA uptake appeared by autoradiography to be associated with phytoplankton in Southern California coastal waters (Fuhrman \& Azam 1982).

The observation that glass fiber filters can cause DFAA release suggests that this commonly-used filter type is inappropriate for these kinds of studies. While we did not test other glass filter types, the effect probably occurs with them as well. Also, because glass fiber filters are commonly used for filtering samples for nutrient analyses, it would be advisable to check for possible leakage of intracellular nutrients by comparison with other filter types, such as $0.2 \mu \mathrm{m}$ Nuclepore ${ }^{\otimes}$.

\section{CONCLUSIONS}

There is a significant potential for error in the measurement of DFAAs (and possibly other dissolved organics) unless care is taken to avoid release of these substances from organisms in the sample. Inadvertent release can also interfere with experiments in which it is assumed that the levels of DFAAs and other dissolved substances are unaffected by sample handling. The following suggestions are given:

(1) Unfiltered samples should be protected from inadvertent exposure to toxic substances such as trace metals and preservatives.

(2) Filtration of samples shortly after collection and before derivatization is recommended in order to prevent DFAA release due to chemical and mechanical procedures involved in analysis. Filtration also protects the HPLC from damage.

(3) Volumes filtered should be small, <25 ml, unless it can be shown that for the water used, larger filtered volumes do not have more DFAAs.

(4) Among different filter types, 0.22 or $0.45 \mu \mathrm{m}$ pore size Millipore ${ }^{\circledR}$ and $0.2 \mu \mathrm{m}$ pore size polycarbonate Nuclepore ${ }^{\mathbb{1}}$ filters are acceptable. $1.0 \mu \mathrm{m}$ pore size Nuclepore ${ }^{8}$ filters and GF/F glass fiber filters can cause release of DFAAs into the filtrate. This should be taken into account in size fractionation studies. 
Acknowledgements. We thank J. Glover for assistance; T. W Bell for helpful discussion; D. Comeau-Fuhrman, S. G. Horrigan, and D. G. Capone for reviewing the manuscript; $M$. Legier for assisting with manuscript preparation. This work was supported by NSF grants OCE-8207523 and OCE8410074 .

\section{LITERATURE CITED}

Azam, F., Hodson, R. E. (1977). Size distribution and activity of marine microheterotrophs. Limnol. Oceanogr. 22: 492-501

Bada, J., Lee, C. (1977). Decomposition and alteration of organic compounds dissolved in seawater. Mar. Chem. 5: 523-534

Burney, C. M., Davis, P. G., Johnson, K. M., Sieburth, J. McN. (1981). Dependence of dissolved carbohydrate concentrations upon small scale nanoplankton and bacterioplankton distributions in the western Sargasso Sea. Mar. Biol. 65: 289-296

Carpenter, E. J., Lively, J. S. (1980). Review of estimates of algal growth using ${ }^{14} \mathrm{C}$ tracer techniques. In: Falkowski, P. G. (ed.) Primary productivity in the sea. Plenum Publ. Corp., New York, p. 161-178

Crawford, C. C., Hobbie, J. E., Webb, K. L. (1974). The utilization of dissolved free amino acids by estuarine micro-organisms. Ecology 55: 551-563

Ferguson, R. L., Sunda, W. G. (1984). Utilization of amino acids by planktonic marine bacteria: importance of clean technique and low substrate additions. Limnol. Oceanogr. 29: $258-274$

Fitzwater, S. E., Knauer, G. A., Martin, J. H. (1982), Metal contamination and its effect on primary production measurements. Limnol. Oceanogr. 27: 544-551

Fuhrman, J. A. (1983). Close coupling between uptake and release of amino acids in seawater. (Abstract). Trans. Am. Geophys. Un. 64: 1095

Fuhrman, J. A., Azam, F. (1980). Bacterioplankton secondary production estimates for coastal waters of British Columbia, Antarctica, and California. Appl. environ. Microbiol. 39: 1085-1095

Fuhrman, J. A., Azam, F. (1982). Thymidine incorporation as a measure of heterotrophic bacterioplankton production in marine surface waters: evalution and field results. Mar. Biol. 66: 109-120

Garrasi, C., Degens, E. T., Mopper, K. (1979). The free amino acid composition of seawater obtained without desalting and concentration. Mar. Chem. 8: 71-85

Glibert, P. M., Lipschultz, F., McCarthy, J. J., Altabet, M. A. (1982). Isotope dilution models of uptake and remineralization of ammonium by marine phytoplankton. Limnol. Oceanogr. 27: 639-650

Goldman, J. C., Dennett, M. R. (1985). Susceptibility of some marine phytoplankton species to cell breakage during filtration and post-filtration rinsing. J. exp. mar. Biol. Ecol. $84: 47-58$

Hagström, ̊̊., Larsson, U., Hörstedt, P., Normark, S. (1979). Frequency of dividing cells, a new approach to the determination of bacterial growth rates in aquatic environments. Appl. environ. Microbiol. 37: 805-812

Harrison, W. G. (1983). Uptake and recycling of soluble reactive phosphorus by marine microplankton. Mar. Ecol. Prog. Ser. 10: 127-135
Hedges, J. I. (1978). The formation and clay mineral reactions of melanoidins. Geochim. cosmochim. Acta. 42: 68-76

Hollibaugh, J. T., Carruthers, A. B., Fuhrman, J. A., Azam, F. (1980). Cycling of organic nitrogen in marine plankton communities studied in enclosed water columns. Mar. Biol. 59: 15-21

Jeffries, H. P. (1969). Seasonal composition of temperate plankton communities: free amino acids. Limnol. Oceanogr. 14: 41-52

Jones, B. N., Paabo, S., Stein, S. (1981). Amino acid analysis and enzymatic sequence determination of peptides by an improved o-phthalidaldehyde precolumn labeling procedure. J. Liq. Chromatogr. 4: 565-586

Jorgensen, N. O. G. (1982). Heterotrophic assimilation and occurrence of dissolved free amino acids in a shallow estuary. Mar. Ecol. Prog. Ser. 8: 145-159

Landry, M. R., Haas, L. W., Fagerness, V. L. (1984). Dynamics of microbial plankton communities: experiments in Kaneohe Bay, Hawaii. Mar. Ecol. Prog. Ser. 16: 127-133

Lindroth, P., Mopper, K. (1979). High performance liquid chromatographic determination of subpicomole amounts of amino acids by precolumn fluorescence derivitization with o-phthaldialdehyde. Analyt. Chem. 51: 1667-74

Mopper, K., Lindroth, P. (1982). Diel and depth variations in dissolved free amino acids and ammonium in the Baltic Sea determined by shipboad HPLC analysis. Limnol. Oceanogr. 27: 336-347

Parsons, T. R., Takahashi, M., Hargrave, B. (1977). Biologica! oceanographic processes. Pergamon Press, New York

Pocklington, R. (1977). Chemical processes and interactions involving marine organic matter. Mar. Chem. 5: 479-496

Sharp, J. H. (1977). Excretion of organic matter by marine phytoplankton: Do healthy cells do it? Limnol. Oceanogr. 22: 381-399

Siebers, D., Hoppenheit, M., Harms, U. (1981). Mercury influences uptake of amino acids by marine bacteria. Mar. Ecol. Prog. Ser. 6: 101-113

Syrett, P. J. (1981). Nitrogen metabolism of microalgae. In: Platt, T. (ed.) Physiological bases of phytoplankton ecology. Can. Bull. Fish. Aquat. Sci. 210: 182-210

Wheeler, P. A. (1983). Phytoplankton nitrogen metabolism. In: Carpenter, E. J., Capone, D. G. (ed.). Nitrogen in the marine environment. Academic Press, New York, p. 309-346

Wheeler, P., North, B., Littler, M., Stephens, G. (1977). Uptake of glycine by natural phytoplankton communities. Limnol. Oceanogr. 22: 900-910

Williams, P. J. le B. (1970). Heterotrophic utilization of dissolved organic compounds in the sea. I. Size distribution of population and relationship between respiration and incorporation of growth substrates. J. mar. biol. Ass. U.K. 50: $859-870$

Williams, P. J. le B. (1981). Incorporation of microheterotrophic processes into the classical paradigm of the planktonic food web. Kieler Meeresforsh. (Sonderh.) 5: 1-28

Williams, P. J. le B., Yentsch, C. S. (1976). An examination of photosynthetic production, excretion of photosynthetic products, and heterotrophic utilization of dissolved organic compounds with reference to results from a coastal subtropical sea. Mar. Biol. 35: 31-40

Wright, R. T., Coffin, R. B. (1984). Factors affecting bacterioplankton density and productivity in salt marsh estuaries. In: Klug, M. J., Reddy, C. A. (ed.) Current perspectives in microbial ecology. ASM Press, Washington D. C., p. $485-494$ 